\title{
Collodion Baby in a Sudanese patient
}

\author{
Mumen Abdalazim Dafallah ${ }^{1}$ and Esraa Ahmed Ragab ${ }^{1}$ \\ ${ }^{1}$ University of Gezira Faculty of Medicine
}

June 24, 2021

\begin{abstract}
The aim of my clinical image is to recall this rare dermatological condition and to highlight instructions to follow in treatment and proper management of the complications that can arise.
\end{abstract}

Title page

Type of Article: clinical image

\section{Title: Collodion Baby in a Sudanese patient}

\author{
Authors \\ Mumen Abdalazim Dafallah Albashier, Faculty of Medicine, University of Gezira, Sudan Mumenab- \\ dalazim36@gmail.com \\ Esraa Ahmed Ragab Mohamed Elamin, Faculty of Medicine, University of Gezira, Sudan Es- \\ raragab96@gmail.com
}

\section{Corresponging Author:}

Mumen Abdalazim Dafallah Albashier, Faculty of Medicine, University of Gezira, Sudan

Tel: $+249968629551,+249965007388$

Email address:mumenabdalazim36@gmail.com

Hosted file

Collodion Baby in a Sudanese patient.docx available at https://authorea.com/users/421636/ articles/527575-collodion-baby-in-a-sudanese-patient 